\title{
Pemanfaatan Teknologi Drone untuk Pembelajaran Geografi Spasial di Tingkat Pendidikan Menengah Atas
}

\author{
${ }^{1 *}$ Danardono, ${ }^{1}$ Priyono, ${ }^{1}$ Kartika Cindi Wulandari, ${ }^{1}$ Danis Novianto \\ ${ }^{1}$ Fakultas Geografi, Universitas Muhammadiyah Surakarta \\ *Penulis korespondensi, email: danardono@ums.ac.id
}

(Received: 16 August 2021/Accepted: 20 October 2021/Published: 31 January 2022)

\begin{abstract}
Abstrak
Munculnya era baru society 5.0 menuntut tiap bidang keilmuan memiliki perkembangan teknologi tinggi, mutakhir, mudah diakses, dan berbasis internet termasuk bidang keilmuan geografi. Salah satu teknologi yang berkembang pada bidang keilmuan geografi yaitu pemanfaatan teknologi drone untuk pemetaan. Akan tetapi perkembangan teknologi di bidang geografi ini belum terintegrasikan di dalam pembelajaran geografi utamanya di tingkat pendidikan menengah. Hal ini disebabkan karena masih kurangnya update keilmuan para pendidik di tingkat pendidikan menengah terkait perkembangan teknologi ini. Hal inilah yang menjadi latar belakang pelaksanaan kegiatan pengabdian ini yang bertujuan untuk mengenalkan dan meningkatkan pemahaman guru di tingkat pendidikan menengah dalam pemanfaatan drone untuk berbagai kajian geografi. Pengabdian dilakukan dengan bentuk sosialisasi terkait teknologi drone, pelatihan dan simulasi pengoperasian drone. Peserta kegiatan sangat antusias dalam mengikuti kegiatan dan mengapresiasi pelaksanaan kegiatan yang menarik dan memberikan banyak pengetahuan bagi peserta. Bahkan, peserta meminta untuk dilaksanakan kegiatan lanjutan yang lebih spesifik membahas pemanfaatan drone pada satu kajian tertentu mulai dari pengumpulan sampai pengolahan datanya.
\end{abstract}

Kata Kunci: Geografi; Pemetaan Drone; Pembelajaran; Society 5.0

\begin{abstract}
The emergence of a new era of society 5.0 requires every scientific field has high technology development, up-to-date, easily accessible, and internet-based, including geography major. One of the technologies that has developed in the geography major is the use of drone technology for mapping. However, technological developments in the field of geography have not been integrated into geography learning, especially at the secondary education level. This is due to the lack of scientific updates for educators at the secondary education level regarding the development of this technology. This is the background for the implementation of this service activity which aims to introduce and improve the understanding of teachers at the secondary education level in the use of drones for various geographical studies. The service is carried out in the form of socialization related to drone technology, training and drone operation simulations. The activity participants were very enthusiastic in participating in the activities and appreciated the implementation of interesting activities and provided a lot of knowledge for participants. In fact, participants asked for further activities that were more specific to discuss the use of drones in a particular study, from data collection to data processing.
\end{abstract}

Keywords : Geography, Drone Mapping, Education, Society 5.0

\section{Pendahuluan}

Sejak dikenalnya era baru yaitu revolusi industri 5.0 atau society 5.0, perkembangan teknologi dalam semua lini kehidupan berkembang pesat. Paradigma yang dipopulerkan pada era 
society 5.0 yaitu pemanfaatan Internet of Things (IoT), Artificial Intelligence (AI), Big Data, dan Robot dalam menyelesaikan masalah pada berbagai lini kehidupan. Adanya era society 5.0 menuntut adanya penggunaan teknologi mutakhir pada tiap sektor kehidupan untuk menunjang aktivitas di dalamnya. Hal ini jelas menuntut adanya migrasi besar-besaran menuju dunia otomatisasi pada berbagai sektor termasuk salah satunya sektor pendidikan (Nastiti dan Abdu, 2020).

Sektor pendidikan menjadi salah satu sektor yang memiliki tuntutan besar untuk beradaptasi dengan perubahan ini. Hal ini terjadi karena sektor pendidikan tidak hanya harus memanfaatkan berbagai macam teknologi mutakhir yang berkembang, tetapi juga harus mampu menyiapkan sumberdaya manusia yang mampu menciptakan teknologi tersebut. Sektor pendidikan harus mampu mencetak generasi yang mampu menguasai perkembangan teknologi yang ada dan menciptakan inovasi baru terkait teknologi tersebut. Jika hal ini tidak tercapai maka sumberdaya manusia yang dihasilkan akan kalah bersaing dan tergantikan dengan robot atau piranti otomatis lainnnya, dengan kata lain generasi yang dihasilkan berupa generasi out of date.

Disisi lain, jika dilihat dari fakta di lapangan masih banyak sektor pendidikan utamanya pendidikan dasar dan menengah di Indonesia yang belum bisa beradaptasi dengan perkembangan teknologi yang pesat ini. Hal ini terlihat dari kurikulum dan materi yang diajarkan masih bersifat konseptual dan sedikit porsi yang bersifat aplikatif. Sistem pembelajaran ini hanya akan menghasilkan generasi yang paham teori tetapi buta terhadap praktek dan inovasi teknologi (Tanjung, 2011). Kondisi ini patut menjadi perhatian dan perlu adanya revolusi besar-besaran dalam dunia pendidikan di Indonesia.

Masih minimnya pembelajaran aplikatif di tingkat pendidikan dasar dan menengah disebabkan karena dua hal. Hal pertama yaitu terkait kurikulum pembelajaran di Indonesia masih belum banyak bisa mewadahi pembelajaran yang bersifat aplikatif. Hal ini terlihat dari masih banyaknya materi mengenai teori dasar yang diberikan tanpa adanya praktek penerapan langsung untuk menghasilkan karya dari teori tersebut. Hal kedua terkait dengan kemampuan tenaga pendidik di Indonesia yang belum merata. Masih banyak tenaga pendidik yang kurang mengikuti perkembangan teknologi dalam bidang keilmuan tertentu sehingga materi yang disampaikan kepada siswa tidak berubah dari tahun ke tahun dan tidak berkembang sesuai perubahan zaman.

Kondisi ini terjadi salah satunya pada mata pelajaran geografi di tingkat pendidikan menegah. Kurikulum dan materi yang diberikan oleh guru geografi di tingkat pendidikan menengah masih belum mengakomodasi materi aplikatif utamanya mengenai perkembangan teknologi di bidang keilmuan geografi. Materi yang diajarkan pada mata pelajaran geografi di tingkat pendidikan menengah masih sebatas terkait penjelasan teori dasar fenomena geografi yang ada di permukaan bumi tanpa disertai dengan pemanfaatan teknologi untuk mengkaji fenomena geografi tersebut. Hal ini menyebabkan siswa pendidikan menengah belum terlalu paham terkait perkembangan teknologi di bidang geografi (Danardono et al., 2020).

Berdasarkan permasalahan yang diterjadi maka perlu adanya upaya konkret untuk meningkatkan pemahaman terkait perkembangan keilmuan geografi di era society 5.0 utamanya bagi para pendidik (guru) di tingkat pendidikan menengah. Hal ini diperlukan agar tenaga pendidik dapat memberikan materi geografi yang sesuai perkembangan era society 5.0. Salah satu langkah yang dapat dilakukan untuk meningkatkan pemahaman tenaga pendidik yaitu dengan mengenalkan dan memberi pelatihan penggunaan berbagai macam teknologi bidang geografi di era society 5.0 pada tenaga pendidik di tingkat pendidikan menengah.

Salah satu teknologi bidang keilmuan geografi era society 5.0 yang dapat dikenalkan dan diajarkan di tingkat pendidikan menengah yaitu pemanfaatan teknologi Unmanned Aerial Vehicle (UAV) atau yang dikenal dengan drone. Teknologi drone dapat didefinisikan sebagai suatu wahana dalam penginderaan jauh berupa pesawat udara yang mampu terbang tanpa awak dan dikendalikan dari darat menggunakan remote kontrol (Suroso, 2016; Casagrande et al., 2018; Garret and Anderson, 2018). Teknologi drone dalam bidang keilmuan geografi dapat digunakan 
untuk membantu dalam pemetaan berbagai sektor baik dalam pemetaan untuk militer sampai untuk pemetaan batas wilayah (Custers, 2016).

Teknologi drone dalam bidang kajian geografi lambat laun mulai tenar, bahkan mulai menggeser aktivitas pemotretan udara dengan wahana pesawat terbang dan data penginderaan jauh yang lain (Utomo, 2017; Suciani dan Rahmadi, 2018). Keunggulan teknologi drone dibandingkan produk penginderaan jauh lainnya yaitu dapat menghasilkan foto udara resolusi tinggi dengan biaya relatif murah, mudah dalam pengoperasian, waktu yang singkat, dan data real time sehingga sangat cocok diterapkan dalam berbagai kajian geografi (Shofiyanti, 2011; Wulan, et al., 2017). Hasil pemetaan dengan drone yang dapat menghasilkan produk foto udara resolusi tinggi sangat cocok diterapkan dalam berbagai kajian geografi seperti kajian hidrologi, geomorfologi, kebencanaan, sosial, budaya (Marfai, et al., 2014), dan juga dalam pemetaan tanah (Hartono dan Darmawan, 2018).

Keunggulan dalam pemanfaatan teknologi drone dalam kajian geografi ini perlu dipahami dan dipelajari juga oleh siswa di tingkat pendidikan menengah. Hal ini dimaksudkan agar siswa pendidikan menengah memiliki ketrampilan bidang geografi yang mengikuti perkembangan zaman. Oleh karena itu agar materi mengenai pemanfaatan drone dapat disampaikan pada tingkat pendidikan menengah maka perlu adanya upaya peningkatan pemahaman guru di tingkat menengah terkait pemanfaatan teknologi ini. Langkah yang dapat ditempuh yaitu dengan melakukan sosialisasi dan pelatihan pemanfaatan teknologi drone dalam bidang keilmuan geografi pada guru di tingkat pendidikan menengah. Bentuk sosialisasi dan pelatihan dikemas dengan adanya praktek di lapangan untuk menggunakan drone sehingga guru dapat merasakan langsung cara menggunakan drone. Kegiatan ini dilaksanakan dengan tujuan untuk mengenalkan dan meningkatkan pemahaman guru di tingkat pendidikan menengah dalam pemanfaatan drone untuk berbagai kajian geografi sehingga pada akhirnya guru dapat mengajarkan kepada siswanya.

\section{Metode}

Metode yang digunakan dalam pelaksanaan kegiatan yaitu sosialisasi, pelatihan, dan simulasi. Sosialisasi dilaksanakan dalam bentuk penyampaian materi, diskusi, dan tanya jawab terkait pengenalan teknologi drone dan contoh pemanfaatannya dalam bidang keilmuan geografi. Sementara, pelatihan dan simulasi dilaksanakan dalam bentuk penyampaian materi cara-cara pengoperasian drone dan praktek langsung penggunaan drone di lapangan.

Pelaksanaan kegiatan pengabdian ini secara garis besar terbagi menjadi tiga bagian yaitu (1) pra-kegiatan; (2) pelaksanaan kegiatan; (3) evaluasi kegiatan. Pra-kegiatan terbagi menjadi tiga kegiatan yaitu (1) koordinasi awal dengan pihak Musyawarah Guru Mata Pelajaran Geografi (MGMP) di Kabupaten Rembang; (2) perijinan resmi kepada pihak MGMP Geografi Kabupaten Rembang; (3) diskusi model rencana kegiatan serta pembuatan materi terkait kegiatan.

Tahap pelaksanaan kegiatan terbagi menjadi 3 metode yaitu (1) metode ceramah berupa sosialisasi terkait pengenalan dan pemanfaatan drone dalam pembelajaran geografi; (2) pelatihan di ruangan terkait cara pengoperasian drone dan hal-hal dasar yang perlu diperhatikan sebelum penggunaan drone; dan (3) simulasi penggunaan drone di lapangan serta pengolahan data hasil pemotretan dengan drone. Tahap terakhir yaitu evaluasi kegiatan dilakukan dengan menampung berbagai saran, masukan, dan testimoni yang nanti digunakan sebagai bahan perbaikan dan pengembangan kegiatan lanjutan pengabdian ini. Selain itu, pada akhir kegiatan ini akan dibuat perjanjian kerjasama berupa Memorandum of Understanding (MoU) dalam pengembangan keilmuan geografi dengan MGMP Geografi di Kabupaten Rembang dan sekitarnya.

Materi yang disampaikan pada kegiatan pengabdian ini diawali dengan pengenalan teknologi dan tantangan bidang keilmuan geografi di era society 5.0. Selanjutnya dikenalkan beberapa perkembangan teknologi di bidang geografi salah satunya yaitu pemanfaatan drone 
untuk pemetaan. Materi dilanjutkan dengan pengenalan teknologi drone secara umum dan dilanjutkan dengan beberapa terapan penggunaan drone dalam menjawab permasalahan pada kajian-kajian bidang geografi. Materi terakhir yang disampikan berupa teknik atau cara penggunaan drone beserta pengolahan data hasil foto dengan drone baik di ruangan secara teori ataupun di lapangan dengan praktek langsung. Selain itu, pada materi terakhir disampaikan pula tentang pemahaman dan aturan dalam penerbangan drone.

Peserta kegiatan pengabdian ini yaitu guru-guru geografi di tingkat pendidikan menengah baik SMA dan MA yang tergabung dalam MGMP Geografi di Kabupaten Rembang, Cepu, Blora, Pati, dan Kudus. Peserta dipilih berupa guru-guru mata pelajaran geografi mengingat guru berperan sebagai ujung tombak pendidikan geografi pada tingkat pendidikan menengah sehingga dapat mengajarkan ilmunya kepada siswa. Selain itu, masih rendahnya pemahaman guru geografi di tingkat pendidikan menengah terkait perkembangan teknologi di bidang geografi utamanya pemanfaatan drone menjadi pertimbangan utama pelaksanaan kegiatan ini. Muara akhir kegiatan ini diharapkan dapat semakin meningkatkan pemahaman guru geografi dalam pengoperasian drone sehingga nantinya dapat diterapkan dalam pembelajaran di kelas. Adanya kemitraan antara pihak Fakultas Geografi UMS dan MGMP Geografi diharapkan juga dapat semakin meningkatkan inovasi pembelajaran geografi berbasis aplikatif di tingkat pendidikan menengah.

\section{Hasil dan Pembahasan}

Kegiatan pengabdian masyarakat ini telah dilaksanakan pada hari Kamis Tanggal 21 November 2019 bertempat di Aula Sekolah Menengah Atas (SMA) Negeri 2 Rembang. Jumlah peserta dari kegiatan yaitu 63 orang yang terdiri dari beberapa guru yang masuk dalam MGMP Geografi di Kabupaten Rembang, Cepu, Blora, dan Pati. Adapun persentase asal peserta pengabdian ini secara lengkap tersaji pada Gambar 1. Guru yang dipilih merupakan guru mata pelajaran geografi agar materi yang disampaikan pada pengabdian ini bisa diterapkan dan diintegrasikan dalam pembelajaran geografi di tingkat pendidikan menengah sehingga siswa juga mempunyai ketrampilan dalam pemanfaatan drone untuk kajian geografi.

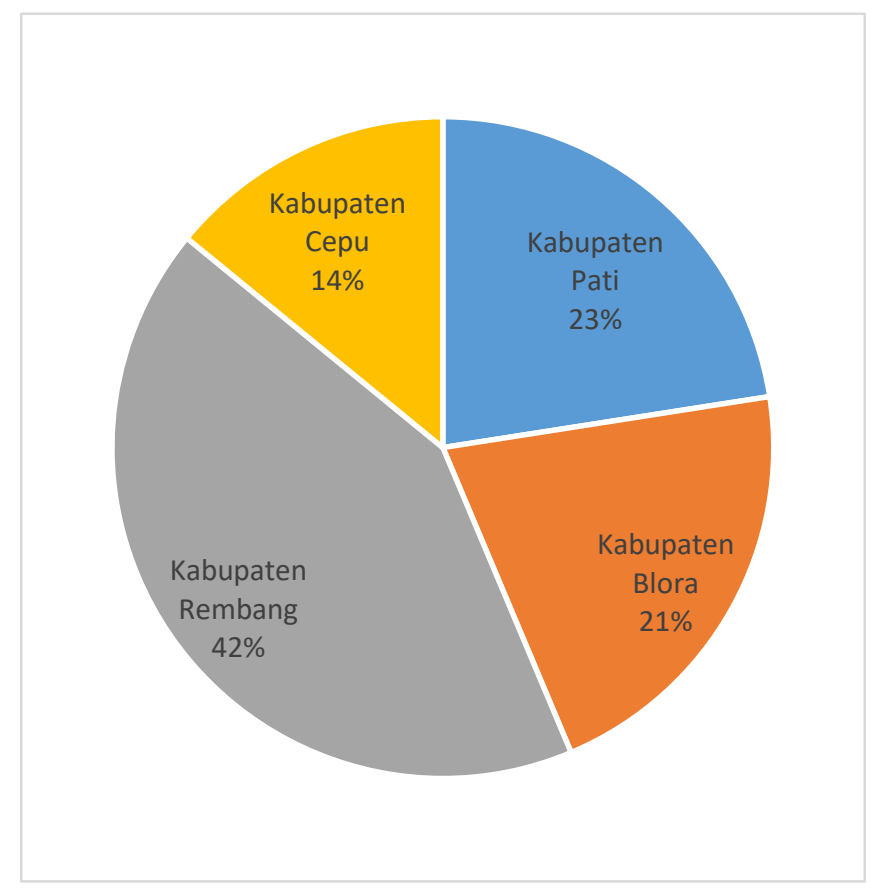

Gambar 1. Diagram Persentase Asal Peserta Kegiatan Pengabdian 
Kegiatan pengabdian masyarakat ini merupakan bagian dari agenda rutin tahunan Fakultas Geografi UMS yang dikemas dalam bentuk roadshow di Pulau Jawa untuk memberikan pengetahuan terkait perkembangan keilmuan geografi di tingkat pendidikan menengah. Pelaksanaan kegiatan pengabdian di Kabupaten Rembang ini diawali dengan adanya komunikasi antara ketua MGMP Geografi Kabupaten Rembang dengan Fakultas Geografi UMS terkait masalah kurangnya updating keilmuan geografi di tingkat pendidikan menengah utamanya yang berkaitan dengan pemanfaatan teknologi. Hasil komunikasi ini kemudian ditindak lanjuti dengan pelaksanaan kegiatan sosialisasi dan pelatihan pemanfaatan drone dalam kajian keilmuan geografi. Namun, sebelum dilaksanakan pengabdian, dilakukan terlebih dahulu mekanisme perijinan resmi kepada pihak MGMP Geografi Kabupaten Rembang dan SMA Negeri 2 Rembang sebagai tuan rumah untuk mengadakan kegiatan ini. Pihak MGMP Kabupaten Rembang dan SMA Negeri 2 Rembang sangat mendukung kegiatan yang akan dilakukan sekaligus memberi fasilitas berupa peminjaman ruang, konsumsi, dan akomodasi bagi peserta. Pelaksanaan pra-kegiatan yang melingkupi koordinasi awal dan perijinan dilakukan selama kurang lebih 1 minggu sebelum pelaksanaan pengabdian dilakukan.

Selanjutnya pelaksanaan kegiatan pengabdian secara umum terbagi menjadi tiga sesi. Sesi pertama diisi dengan sosialisasi berupa ceramah langsung. Materi yang disampaikan pada sesi pertama diawali dengan memberikan penyegaran dan pemahaman mengenai perkembangan teknologi di bidang geografi pada era society 5.0. Selanjutnya diberikan salah satu contoh teknologi yang sedang banyak digunakan dalam kajian keilmuan geografi saat ini yaitu drone mapping. Sebagai pengantar untuk materi pemanfaatan drone, diberikan dahulu materi terkait serba-serbi drone secara umum yang kemudian dilanjutkan dengan materi bentuk-bentuk terapan pemanfaatan drone dalam kajian bidang geografi. Saat pemberian materi diselipkan juga beberapa waktu untuk tanya jawab seputar teknologi drone dan pemanfaatannya. Saat sesi diskusi sesi pertama, peserta terlihat antusias terhadap materi yang diberikan. Hal ini terlihat dari banyaknya pertanyaan oleh peserta baik mengenai dasar teknologi drone sampai kepada terapan teknologi drone yang memungkinkan bisa diajarkan di sekolah menengah. Beberapa pertanyaan yang disampaikan oleh peserta dapat dilihat pada Tabel 1. Foto kegiatan saat pemberian materi pada sesi pertama dapat dilihat pada Gambar 2.

Tabel 1. Daftar Beberapa Pertanyaan dan Jawaban Saat Sesi Diskusi

\begin{tabular}{cll}
\hline No & \multicolumn{1}{c}{ Pertanyaan } & \multicolumn{1}{c}{ Jawaban } \\
\hline 1. & Hal apa saja yang perlu dilakukan agar saat & Pada dasarnya menerbangkan drone sama \\
& menerbangkan drone tidak terjadi crash ? & seperti menerbangkan pesawat biasa, hal \\
& awal yang perlu dicek adalah dari fungsi \\
& alat baik drone dan remote. Pastikan \\
& semua alat dalam keadaan baik dan \\
& memiliki baterai yang cukup. Selanjutnya \\
& pilot perlu mengerti kondisi wilayahnya, \\
& pastikan sinyal remote dan drone tanpa \\
& gangguan, tidak terdapat penghalang untuk \\
& drone terbang, serta peraturan-peraturan \\
& yang perlu diterapkan ketika \\
2. Jenis drone apa yang dapat dioperasikan dengan & menerbangkan drone. \\
mudah dan biaya murah ? & Jenis drone yang dapat dimanfaatkan yaitu \\
& ultra light drone dan quadcopter. Saat ini \\
& sudah banyak merk drone yang dijual di \\
& pasaran melalui $e$-commerce, mulai dari \\
& yang sangat murah dan sangat mahal. \\
& Salah satu drone yang dapat dimanfaatkan \\
& baik untuk keperluan entertain dan \\
& pemetaan yaitu quadcopter yang \\
dikeluarkan oleh DJI. Teknologi
\end{tabular}


3. Software apa yang diperlukan untuk menerbangkan dan mengolah data drone ? quadcopter selain lebih murah juga sangat ramah terhadap pengguna pemula.

Untuk menerbangkan drone secara freeflight dapat menggunakan aplikasi DJI-GO yang tersedia di platform Android dan IOS. Sementara untuk kebutuhan pemetaan dapat menggunakan aplikasi Drone Deploy atau Pix4D Capture. Hasil data pemetaan drone dapat diolah dengan menggunakan software Agisoft atau Pix4D.

4. Apa hasil kajian sederhana yang dapat diajarkan ke siswa terkait data hasil drone mapping ?
Data hasil drone mapping dapat dimanfaatkan untuk berbagai kepentingan dari yang bersifat sederhana sampai kompleks, contoh hal sederhana yaitu untuk mengetahui lokasi rumah, lokasi bangunan tertentu, untuk mengetahui luasan terdampak banjir rob

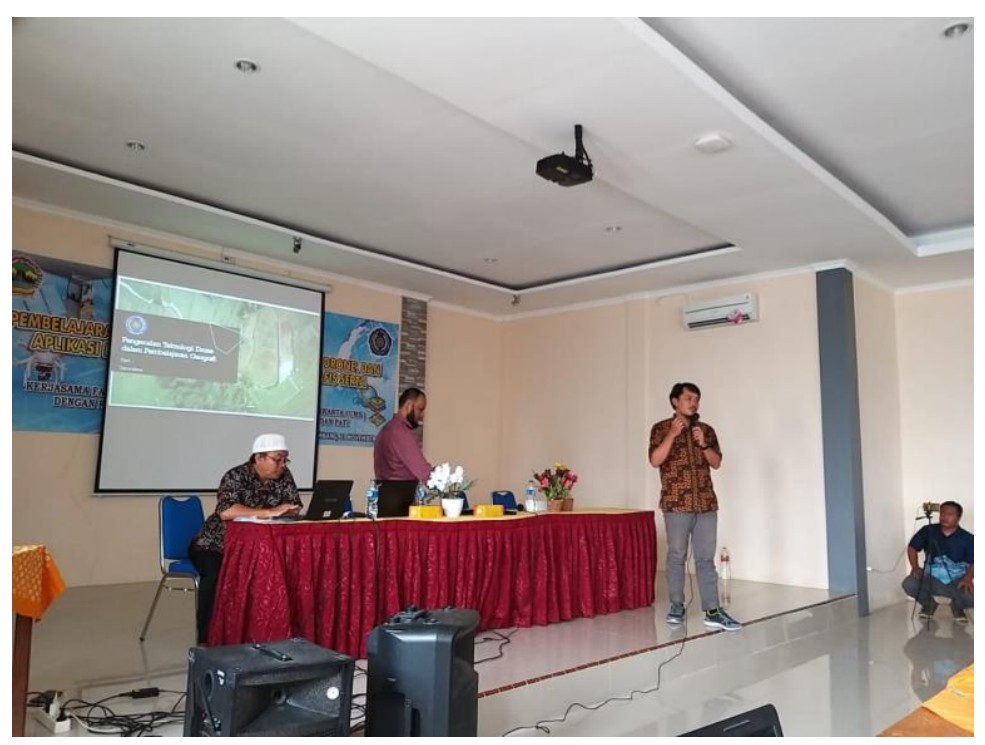

Gambar 2. Penyampaian Materi Sesi 1 Terkait Teknologi Drone dan Pemanfaatannya

Setelah sesi pertama selesai, dilanjutkan ke sesi kedua. Sesi kedua dikemas dalam bentuk pelatihan untuk memberikan pemahaman bagi peserta cara pengoperasian drone. Kegiatan pada sesi kedua ini masih dilakukan di dalam ruangan. Sesi ini memberikan materi dasar terkait fungsifungsi tombol dalam drone beserta hal-hal yang perlu diperhatikan sebelum dan saat menerbangkan drone. Sesi kedua ini dilaksanakan untuk memberikan bayangan bagi peserta untuk pelaksanaan simulasi penerbangan drone pada sesi ketiga. Adapun foto kegiatan pada sesi kedua terkait teknis pengoperasian drone tersaji pada Gambar 3. 


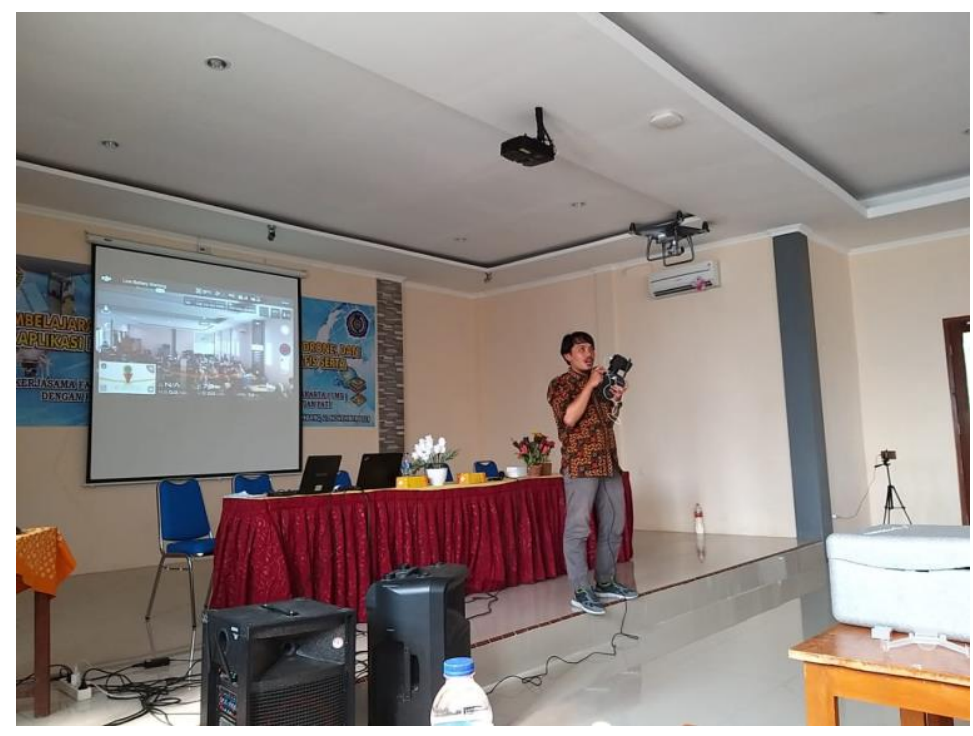

Gambar 3. Penyampaian Materi Sesi Kedua : Cara Pengoperasian Teknologi Drone

Sesi ketiga dilaksanakan di lapangan untuk simulasi praktek langsung penerbangan drone. Simulasi dilaksanakan agar peserta dapat merasakan langsung cara menerbangkan drone yang nanti hasil foto udaranya dapat digunakan untuk mengkaji permasalahan dalam geografi. Foto kegiatan simulasi penerbangan drone di lapangan tersaji pada Gambar 4. Respon peserta pada sesi kedua dan ketiga lebih antusias untuk belajar cara mengoperasikan drone. Hal ini terlihat dari banyaknya peserta yang ingin mencoba sendiri menerbangkan drone. Namun, karena keterbatasan waktu, maka hanya perwakilan beberapa peserta saja yang berkesempatan untuk mencoba menerbangkan drone. Sesi simulasi sekaligus untuk memperoleh data foto udara yang nantinya digunakan untuk sesi selanjutnya terkait pengolahan data hasil pemotretan drone.

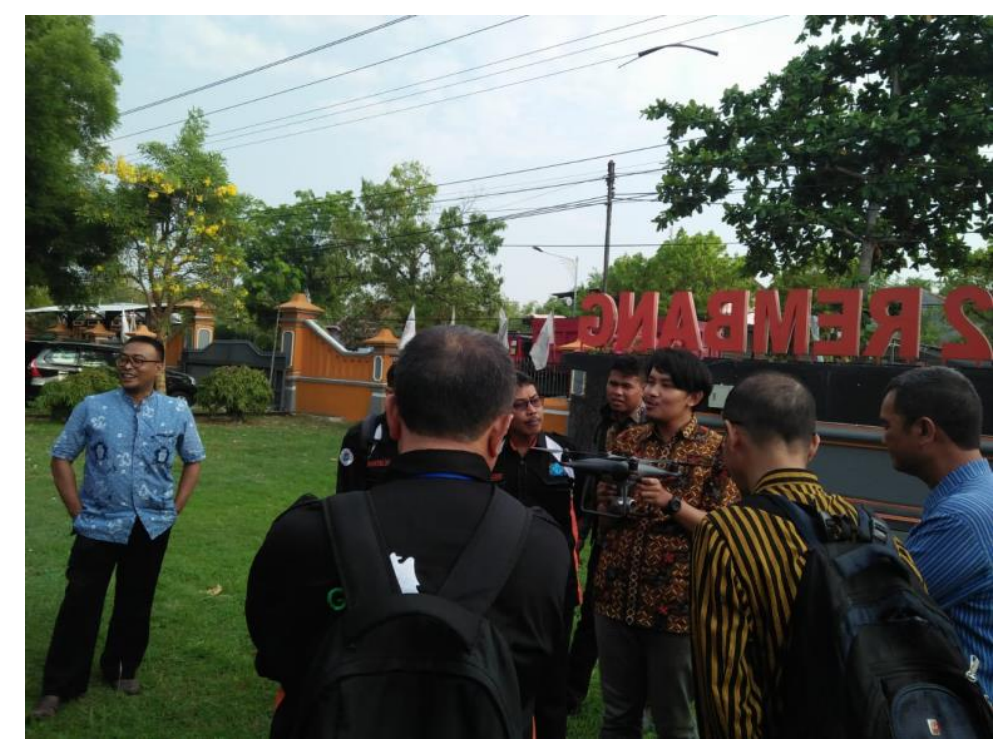

Gambar 4. Simulasi Penerbangan Drone di Lapangan

Sesi terakhir yaitu pemberian materi terkait pengolahan data hasil pemotretan udara menggunakan data foto yang dihasilkan pada saat sesi simulasi. Peserta diminta untuk melakukan bersama proses pengolahan data foto udara dengan menggunakan software Agisoft yang terlebih dahulu sudah diberikan kepada masing-masing peserta. Bagi peserta yang membawa perangkat laptop dapat langsung praktek di tempat untuk mengolah data foto udara drone yang didampingi 
langsung oleh fasilitator. Adapun contoh foto udara hasil olahan peserta dapat dilihat pada Gambar 5.

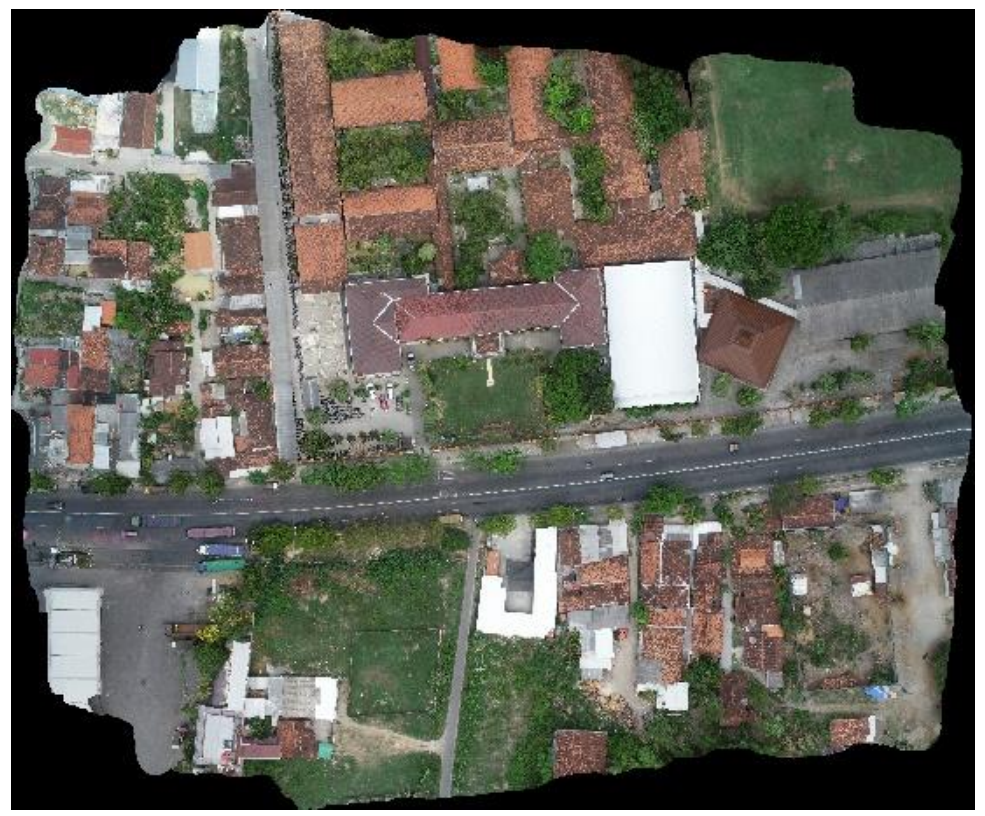

Gambar 5. Contoh Hasil Pemrosesan Foto Udara

Tahap terakhir dari kegiatan pengabdian ini berupa evaluasi kegiatan. Evaluasi kegiatan dinilai sepenuhnya oleh peserta. Hasil kegiatan pengabdian mendapat respon yang baik dan memberikan manfaat yang besar bagi guru geografi di tingkat pendidikan menengah. Hal ini terlihat dari beberapa testimoni yang disampaika oleh peserta. Testimoni yang disampaikan oleh peserta sebagian besar mengungkapkan bahwa kegiatan ini berlangsung menarik dan dikemas dengan metode yang interaktif sehingga semua peserta menjadi fokus dan semakin paham mengenai pemanfaatan drone dalam kajian geografi. Selain itu, peserta juga memberikan saran yang dapat menjadi masukan perbaikan bagi kegiatan lanjutan yaitu terkait alokasi waktu yang sangat minim dan adanya fokus materi pelatihan pada satu bidang tertentu saja sehingga alur pengumpulan sampai analisis data dapat diketahui peserta. Adanya saran tersebut juga menjadi bahan pertimbangan pelaksanaan kegiatan lanjutan di MGMP Geografi Kabupaten Rembang dan sekitarnya dengan tema pemanfaatan drone dengan kajian lebih spesifik.

Selain memberikan manfaat bagi guru geografi di wilayah Kabupaten Rembang dan sekitarnya, keberlanjutan dari kegiatan pengabdian ini berupa terjalinnya kemitraan antara Fakultas Geografi UMS dengan MGMP Geografi di Kabupaten Rembang, Cepu, Blora, dan Pati. Bentuk kemitraan tertuang dalam dokumen kesepakatan atau MoU antara kedua belah pihak. Kemitraan ini dilaksanakan untuk meningkatkan kompetensi guru geografi dalam pembelajaran geografi di kelas. Tujuan utama dari kegiatan kemitraan ini berupa inovasi pada mata pelajaran geografi yang lebih berbasis pada perkembangan teknologi era society 5.0.

\section{Simpulan}

Perkembangan teknologi di era society 5.0 menuntut adanya inovasi pembelajaran keilmuan geografi di tingkat pendidikan menengah yang lebih aplikatif dan berbasis pada pengembangan teknologi. Salah satu teknologi yang dapat dikenalkan dan diajarkan pada tingkat pendidikan menengah yaitu pemanfaatan teknologi drone dalam bidang kajian geografi sehingga siswa memiliki ketrampilan tersebut. Adanya kegiatan sosialisasi pemanfaatan drone dalam keilmuan geografi pada MGMP Geografi di Kabupaten Rembang, Cepu, Blora, Pati, dan Kudus dapat memberikan pengetahuan dasar mengenai pengoperasian teknologi drone untuk 
pengembangan mata pelajaran geografi di tingkat pendidikan menengah. Selain itu, adanya kegiatan pelatihan dan simulasi pemetaan dengan drone dapat menambah ketrampilan para guru di wilayah Kabupaten Rembang dan sekitarnya dalam mengoperasikan teknologi drone sehingga dapat ditularkan kepada seluruh siswanya. Respon dari guru peserta kegiatan sangat antusias untuk belajar lebih dalam mengenai drone mapping. Hal ini terlihat dari banyaknya pertanyaan yang diajukan ketika sesi diskusi dan adanya keinginan dari seluruh peserta untuk melaksanakan kegiatan lanjutan yang lebih spesifik terkait dengan pemanfaatan drone untuk bidang keilmua geografi tertentu mulai dari awal pengumpulan sampai pengolahan datanya.

\section{Persantunan}

Ucapan terima kasih penulis sampaikan kepada seluruh pihak yang telah membantu jalannya pengabdian ini.

\section{Referensi}

Casagrande, G., Sik, A., Szabo, G. (2018). Small Flying Drones. Netherlands: Springer International Publishing.

Custers, B. (2016). The Future of Drone Us: Opportunities and Threats from Ethical and Legal Perspectives. Netherlands: Springer International Publishing.

Danardono, Sunariya, M.I.T., Fikriyah, V.N. (2020). Peningkatan Ketrampilan Siswa dalam Menghadapi Perkembangan Keilmuan Geografi Era 4.0 Melalui Pengenalan Drone Mapping. Aksiologiya: Jurnal Pengabdian Kepada Masyarakat, 5 (1), 104-111.

Garret, B., Anderson, K. (2018). Drone Methodologies: Taking Flight in Human and Physical Geography. Transactions of the Institute of British Geographers, 43(3), 341-359.

Hartono, D., dan Darmawan, S. (2018). Pemanfaatan Unmanned Aerial Vehicle (UAV) Jenis Quadcopter untuk Percepatan Pemetaan Bidang Tanah. Reka Geomatika, 2018 (1), 3040.

Marfai, M. A., Rosaji, F.S.C., Cahyadi, A., Ghozali, M. R. (2014). Analisis Dinamika Pantai di Teluk Baron Menggunakan Teknologi Pesawat Tanpa Awak. Prosiding Pekan Ilmiah Tahunan Ikatan Geograf Indonesia (PIT IGI) 2014.

Nastiti, F.E., Abdu, A.R.N. (2020). Kajian: Kesiapan Pendidikan Indonesia Menghadapi Era Society 5.0. Edcomtech : Jurnal Kajian Teknologi Pendidikan, 5 (1), 61-66.

Shofiyanti, R. (2011). Teknologi Pesawat Tanpa Awak untuk Pemetaan dan Pemantauan Tanaman dan Lahan Pertanian. Informatika Pertanian, 20 (2), 58-64.

Suciani, A. dan Rahmadi, T. (2018). Pemanfaatan Drone DJI Phantom 4 untuk Identifikasi Batas Administrasi Wilayah. Jurnal Geografi, 11 (2), 218-223.

Suroso, I. (2016). Peran Drone/ Unmanned Aerial Vehicle (UAV) Buatan STTKD dalam Dunia Penerbangan. Program Studi Teknik Aeronautika, Sekolah Tinggi Teknologi Kedirgantaraan.

Tanjung, A. (2011). Penggunaan Teknologi \& Media Massa dalam Pembelajaran Geografi. Jurnal Pendidikan Geografi, 16 (1), 71-76.

Utomo, B. (2017). Drone untuk Percepatan Pemetaan Bidang Tanah. Media Komunikasi Geografi, 18 (2), 146-155.

Wulan, T. R., Ambarwulan, W., Putra, A. S., Ibrahim, F., Putra, M. D., Maryanto, D., Pinem, F., Maulana, E. (2017). Pemetaan Cepat Kawasan Terdampak Bencana Longsor dan Banjir di Kabupaten Bangli, Provinsi Bali. Majalah Geografi Indonesia, 31 (2), 44 - 50.

(C) 2022 by the authors. Submitted for possible open access publication under the terms and conditions of the Creative Commons Attribution (CC-BY-NC-ND) license (http://creativecommons.org/licenses/by/4.0/). 